\title{
POŠTA
}

TELEKOMUNIKÁCIE A

ELEKTRONICKY OBCHOD

\section{OCEŇOVANIE OPCIÍ POMOCOU BLACK - SCHOLESOVHO MODELU A POMOCOU BINOMICKÝCH STROMOV}

\author{
Lucia Vrábelová*
}

\begin{abstract}
This paper deals with financial derivates pricing using the Black - Scholes pricing formulas and using the Binomial Tree Model. The price of call option calculated from Black Scholes model using the Monte Carlo simulation of stock price path is compared with the price calculated from Binomial Model. The error of this two numerical methods is estimated.
\end{abstract}

Úvod

Oceňovanie opcií na akcie a na iné finančné nástroje je vel'mi dôležitou súčast'ou obchodovania s opciami. Cena opcie musí byt' správne stanovená, aby sa predišlo možným špekuláciám a arbitrážnym príležitostiam, ktoré predstavujú pre obchodníka bezrizikový zisk. Black - Scholesov model oceňovania opcií je dnes najpoužívanejším nástrojom na stanovenie ceny opcie. Ceny vypočítané pomocou tohto modelu sú prakticky totožné so skutočnými cenami na finančných trhoch. Metóda binomických stromov je d'alšou numerickou metódou oceňovania opcií. Článok uvádza porovnanie ceny opcie na akciu so zadanými parametrami stanovenej pomocou Black - Scholesovho modelu a pomocou binomického stromu a odhaduje chybu pri jednotlivých metódach.

\section{Základné pojmy}

- Finančný derivát je finančný nástroj, ktorého hodnota závisí na hodnote iného finančného aktíva (akcia, burzový index, výmenný kurz).

- Opcia je finančný derivát, ktorý dáva jej vlastníkovi právo kúpit' / predat' dané aktívum (napr. akciu) v danom čase $T$ v budúcnosti za vopred dohodnutú realizačnú cenu $X$. Vyrovnanie opcie nie je povinné, opcia môže vypršat' bez uplatnenia.

- Call opcia je kúpna opcia, zaist’uje vlastníkovi právo na kúpu. Put opcia je predajná opcia, dáva vlastníkovi právo predat' aktívum.

\section{Black - Scholesov model oceňovania opcií}

Black - Scholesov model oceňovania finančných derivátov vychádza $\mathrm{z}$ teórie stochastických procesov ${ }^{1}$.

Nech platí, že náhodná premenná $x$ spĺn̆a Itoov proces

$$
d x=a(x, t) d t+b(x, t) d z \text {. }
$$

Nech $S$ je cena akcie, $f$ je cena derivátu akcie. Nech platí, že $f$ spíňa Itoovu lemu ${ }^{2}$ :

\footnotetext{
* Mgr. Lucia Vrábelová, Katedra spojov, Fakulta prevádzky a ekonomiky dopravy a spojov, Žilinská univerzita, Univerzitná 1, 01026 Žilina, tel.: 5133140, e-mail: Lucia.Vrabelova@fpedas.utc.sk

${ }^{1}$ Bližšia teória stochastických procesov, pozri [1]

${ }^{2}$ Plné znenie Itoovej lemy, pozri [2]
} 


$$
d f=\left(\frac{\partial f}{\partial t}+\frac{\partial f}{\partial S} \mu S+\frac{1}{2} \frac{\partial^{2} f}{\partial S^{2}} \sigma^{2} S^{2}\right) d t+\frac{\partial f}{\partial S} \sigma S d z,
$$

kde $f=f(S, t)$ je cena derivátu akcie, táto je funkciou premennej $S$ a času $t, \mu$ je očakávaná miera návratnosti akcie $S$ daná v \% z ceny akcie, $\sigma$ je volatilita (miera rizika akcie), daná tiež v \% z ceny akcie. Premenná $d z$ spĺn̆a Wienerov proces, teda platí

$$
d z=\sqrt{d t} \varepsilon,
$$

kde $\varepsilon$ je náhodný výber z normovaného normálneho rozdelenia.

Nech platia nasledujúce predpoklady:

1. Cenu akcie $S$ môžeme popísat' geometrickým Brownovym pohybom

$$
\Delta S=\mu S \Delta t+\sigma \Delta z=\mu S \Delta t+\sigma S \sqrt{\Delta t} \varepsilon
$$

s konštantnými parametrami $\mu$ a $\sigma, \varepsilon \sim N(0,1)$.

2. Je možný predaj nakrátko ${ }^{3}$ s plným využitím výnosu (nie je potrebné žiadne krytie).

3. Transakčné náklady a dane sú nulové. Všetky cenné papiere sú l'ubovol'ne delitel'né.

4. Akcia neposkytuje počas životnosti derivátu žiadne dividendy.

5. Neexistuje príležitost' pre arbitráž.

6. Obchodovanie s cennými papiermi je spojité.

7. Bezriziková úroková miera $r$ je konštantná a rovnaká pre všetky doby viazanosti.

Portfólio $\pi$ nech je bezrizikové. Tvorí ho: -1 derivát $f$,

$$
\frac{\partial f}{\partial S} \text { akcií } S \text {. }
$$

Portfólio je vytvorené tak, aby poskytovalo istý výnos rovný bezrizikovej úrokovej sadzbe $r$. Tento výnos bude dosiahnutý vždy, pri poklese aj vzraste ceny akcie.

Hodnota portfólia na začiatku je $\pi=-f+\frac{\partial f}{\partial S} S$.

Zmena hodnoty portfólia za čas $\Delta t$ je $\Delta \pi=-\Delta f+\frac{\partial f}{\partial S} \Delta S$.

Dosadením rovníc (2) a (4) do tejto rovnice s použitím predpokladu, že portfólio je bezrizikové, dostávame Black - Scholesovu parciálnu diferenciálnu rovnicu ${ }^{4}$

$$
r f=\frac{\partial f}{\partial t}+r S \frac{\partial f}{\partial S}+\frac{1}{2} \sigma^{2} S^{2} \frac{\partial^{2} f}{\partial S^{2}}
$$

Stanovením okrajových podmienok a počiatočnej podmienky, ktoré splńa európska call opcia získame riešenie rovnice (5) pre túto európsku call opciu. Toto riešenie je dané: ${ }^{5}$

kde

$$
c=S N\left(d_{1}\right)-X e^{-r(T-t)} N\left(d_{2}\right),
$$

$$
\begin{aligned}
& d_{1}=\frac{\ln \frac{S}{X}+\left(r+\frac{\sigma^{2}}{2}\right)(T-t)}{\sigma \sqrt{T-t}} \\
& d_{2}=d_{1}-\sigma \sqrt{T-t} .
\end{aligned}
$$

\footnotetext{
${ }^{3}$ Predaj akcie nakrátko znamená, že ak investor očakáva pokles ceny akcie, „požičia“ si akciu od niekoho, kto ju vlastní a predá ju, zároveň vstúpi do pozície v call opcii na túto akciu. Pri uplatnení call opcie túto akciu kúpi a vráti majitel’ovi. Pri takomto obchodovaní sa v praxi vyžaduje peňažné krytie ako záruka za pôžičku.

${ }^{4}$ Bližšie odvodenie pozri [2].

${ }^{5}$ Bližšie odvodenie vzorca pozri [2]
} 
Funkcia $N(x)$ je distribučná funkcia normovaného normálneho rozdelenia.

Medzi cenou európskej call opcie a put opcie platí vzt’ah, ktorý sa nazýva put - call parita:

$$
c+X e^{-r(T-t)}=p+S .
$$

Cenu európskej put opcie sa dá vypočítat’ z Black - Scholesovej rovnice rovnakým spôsobom ako cenu call opcie, alebo pomocou (7). Vzorec pre cenu európskej put opcie $p$ je:

$$
p=X e^{-r(T-t)} N\left(-d_{2}\right)-S N\left(-d_{1}\right) \text {. }
$$

\section{Oceňovanie opcií pomocou Black - Scholesovho vzorca}

Použijeme vzorec (6) na výpočet ceny európskej call opcie s realizačnou cenou $X$ na akciu s počiatočnou cenou $S$. Zvolíme očakávanú návratnost' akcie $\mu$, volatilitu $\sigma$, bezrizikovú úrokovú mieru $r$. Zvolíme dížku časového kroku $\Delta t$. Na výpočet ceny call opcie na takúto akciu použijeme nasledujúci postup (Monte Carlo metóda):

1. Urobíme náhodný výber z rozdelenia $N(\mu \Delta t, \sigma \sqrt{\Delta t})$;

2. použitím vzt’ahu (4) vypočítame zmenu ceny akcie $\Delta S$;

3. na začiatku d'alšieho časového intervalu bude cena akcie $S$ rovná predchádzajúcej cene zmenenej o $\Delta S$;

4. postup opakujeme potrebný počet krát;

5. vypočítame ceny call opcie na akciu s poslednými cenami z kroku 3;

6. ceny call opcií spriemerujeme;

7. priemer diskontujeme do času 0 .

Diskontovaný priemer z kroku (7) je odhadom ceny call opcie s danou realizačnou cenou $X$ na akciu s danou počiatočnou cenou $S$.

\section{Oceňovanie opcií pomocou binomických stromov}

Binomické stromy sú vel'mi používanou numerickou metódou na oceňovanie opcií alebo iných finančných derivátov. Vel'kou výhodou tejto metódy je jej univerzálnost', pomocou binomických stromov sa dá ocenit' l'ubovol'ný finančný derivát. Takisto je možné pomocou tejto metódy oceňovat' aj deriváty na akciu poskytujúcu dividendy a path dependent deriváty ${ }^{6}$. Binomický strom reprezentuje možný vývoj ceny akcie počas doby životnosti derivátu. V modeli pracujeme len s diskrétnym časom, teda predpokladáme zmenu ceny akcie vždy po uplynutí časového obdobia $\Delta t$.

Nech portfólio $\pi$ tvorí: $\quad-1$ derivát $f$,

$\Delta$ akcií $S$.

Nech počiatočná cena akcie je $S$. Binomický model predpokladá, že $S$ môže po časovom kroku $\Delta t$ len vzrást' na hodnotu $S_{u}=S \cdot u$ alebo poklesnút' na hodnotu $S_{d}=S \cdot d$, pričom $u$ je koeficient vzrastu, $d$ je koeficient poklesu. Nech $f_{u}$ je cena derivátu akcie pri vzraste akcie na hodnotu $S_{u}$ a $f_{d}$ je cena derivátu akcie pri poklese ceny akcie na $S_{d}$. Túto situáciu znázorňuje nasledujúci jednokrokový binomický strom:

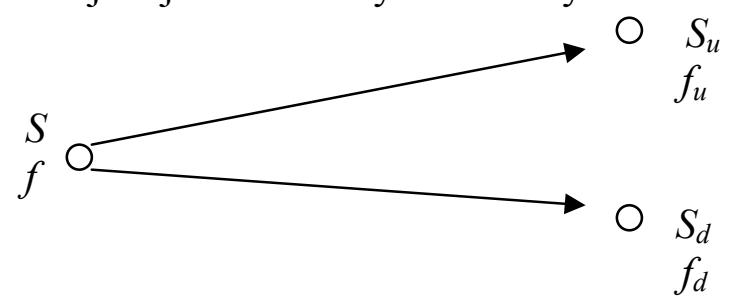

Obr. 1 Jednokrokový binomický model

\footnotetext{
${ }^{6}$ opcie, ktorých payoff závisí od cesty, ktorou sa vyvíjala cena akcie počas doby životnosti derivátu
} 
Počet akcií $\Delta \mathrm{v}$ portfóliu bude taký, aby portfólio bolo bezrizikové, teda aj pri poklese aj pri vzraste ceny akcie portfólio prináša istý zisk rovný bezrizikovej úrokovej miere $r$.

Potom budúca hodnota $\pi$ pri vzraste ceny akcie bude $S \cdot u \cdot \Delta-f_{u}$ a hodnota $\pi$ pri poklese ceny akcie bude $S \cdot d \cdot \Delta-f_{d}$.

Pretože portfólio je bezrizikové, obe tieto hodnoty sa rovnajú. $Z$ toho vyplýva, že potrebný počet akcií v portfóliu $\Delta$ je:

$$
\Delta=\frac{f_{u}-f_{d}}{S_{u}-S_{d}}
$$

Súčasná hodnotu portfólia je rovná jeho budúcej hodnote diskontovanej do času 0 pri bezrizikovej úrokovej miere $r$ :

$$
S H_{\pi}=e^{-r \Delta t}\left(p \cdot f_{u}+(1-p) \cdot f_{d}\right), p=\frac{e^{r \Delta t}-d}{u-d} .
$$

Potom cenu derivátu je

$$
f=e^{-r \Delta t}\left(p \cdot f_{u}+(1-p) \cdot f_{d}\right) .
$$

Č́́slo $p$ predstavuje pravdepodobnost' nárastu ceny akcie, číslo $1-p$ predstavuje pravdepodobnost' poklesu ceny akcie.

Uvedený jednokrokový binomický model sa dá jednoduchým spôsobom rozšírit' na viackrokový, pričom vzorce zostávajú v platnosti.

Pomocou vzorcov (9) - (11) sa dá ocenit' l'ubovolný derivát európskeho typu.

\section{Príklad} $=\$ 18$,

Majme napríklad akciu s počiatočnou cenou $S=\$ 20$ a realizačnou cenou call opcie $X$ $u=1,1, d=0,9$. Nasledujúci obrázok ukazuje príklad výpočtu ceny takejto call opcie na 3 krokovom binomickom strome, $\Delta t=0,0833$ (1 mesiac).

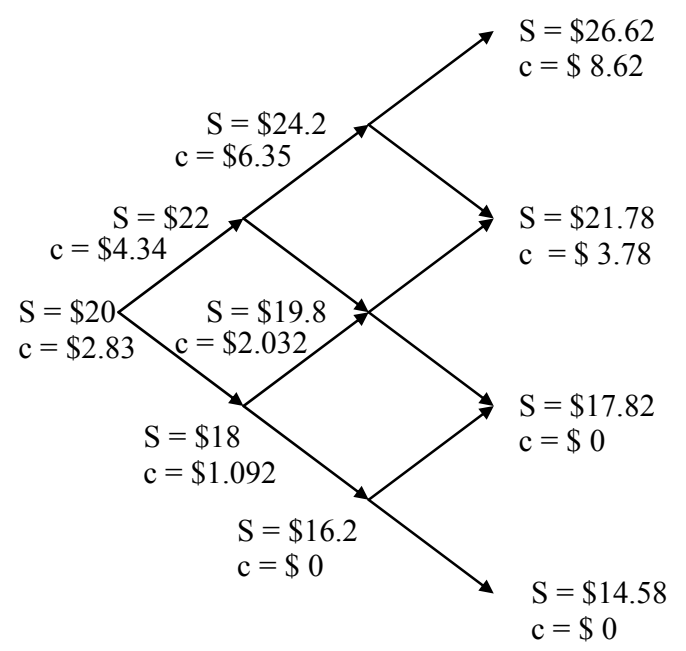

Obr. 2 Ocenenie call opcie s $\mathrm{X}=\$ 18$ na akciu s $\mathrm{S}=\$ 20$ pomocou binomického stromu

Cena call opcie v čase $T$ je $c=\max \left(S_{T}-X, 0\right)$. Týmto spôsobom sa vypočítajú ceny call opcií v koncových bodoch stromu a potom postupom v strome sprava dolava ceny call opcie sa počítajú pomocou (11). Potom cena call opcie v súčasnosti je $c=\$ 2,83$. 
V praxi sa väčšinou používajú 30 a viackrokové binomické stromy. Čím menšie časové úseky zvolíme, tým presnejšie bude cena derivátu stanovená. Hodnoty $u$ a $d$ sa stanovujú z volatility ceny akcie $\sigma$ pomocou nasledujúcich vzorcov:

$$
u=e^{\sigma \sqrt{\Delta t}}, d=e^{-\sigma \sqrt{\Delta t}} .
$$

\section{Porovnanie oceňovania call opcií pomocou Black - Scholesovho vzorca a pomocou binomických stromov}

\section{Black - Scholesov model:}

Zvolíme parametre $S=\$ 20, X=\$ 15, r=0,10, \sigma=0,15, \mu=0,10, \Delta t=0,001$. Porovnáme cenu call opcie na túto akciu vypočítanú pomocou vzorca (6) a pomocou binomického stromu. Použijeme 10 - krokový binomický strom a tomu zodpovedajúcich 10 časových krokov v simulácii vývoja ceny akcie. Simuláciu vývoja ceny akcie opakujeme 1000 krát.

Dostávame nasledujúce výstupy:

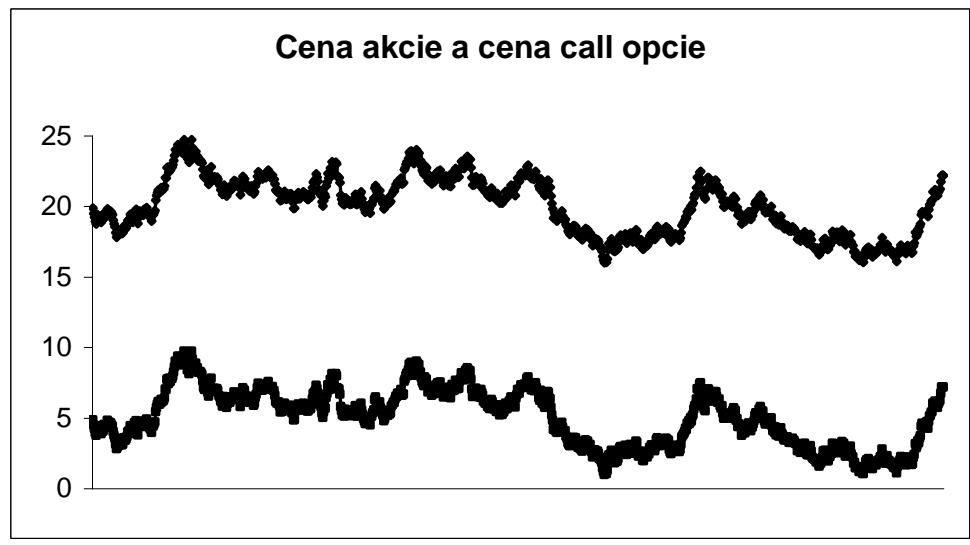

Obr 3 Ocenenie opcie pomocou Black - Scholesovho vzorca (väčšie hodnoty predstavujú cenu akcie, menšie hodnoty cenu opcie)

$\begin{array}{ll}\text { Priemerná cena opcie: } & 5,031 \\ \text { Diskontovaný priemer: } & 5,026 \\ \text { Skutočná cena opcie: } & 5,015\end{array}$

Priemerná cena opcie je diskontovaná do času 0 (teda o čas $T=10 \cdot \Delta t$ ) pri bezrizikovej úrokovej miere $r$. Táto diskontovaná cena predstavuje odhad ceny danej call opcie pomocou Black - Scholesovho modelu.

Skutočná cenu opcie sa vypočíta z pôvodnej ceny akcie $S=\$ 20$ znovu použitím vzorca (6), pričom $T=10 \cdot \Delta t$.

\section{Binomický model:}

Pri binomickom strome sa parametre $u$ a $d$ vypočítajú pomocou (12) a hodnotu pravdepodobnosti $p$ pomocou (10). Po dosadení do vzorca (12) budú hodnoty koeficientov $u$ a $d$ :

$$
\begin{aligned}
& u=1,0047 \\
& d=0,9953
\end{aligned}
$$

a po dosadení do (10) hodnota pravdepodobnosti pohybu ceny akcie smerom nahor je:

$$
p=0,51 \text {, }
$$

a teda pravdepodobnost' pohybu ceny akcie smerom nadol je rovná 


$$
1-p=0,49 \text {. }
$$

Hodnoty akcie v jednotlivých bodoch v strome sa vypočítajú z počiatočnej hodnoty $S$ $=\$ 20$ vždy podl'a

$$
\begin{aligned}
& S_{u}=S \cdot u \\
& S_{d}=S \cdot d
\end{aligned} .
$$

Situáciu znázorňuje nasledujúci strom:

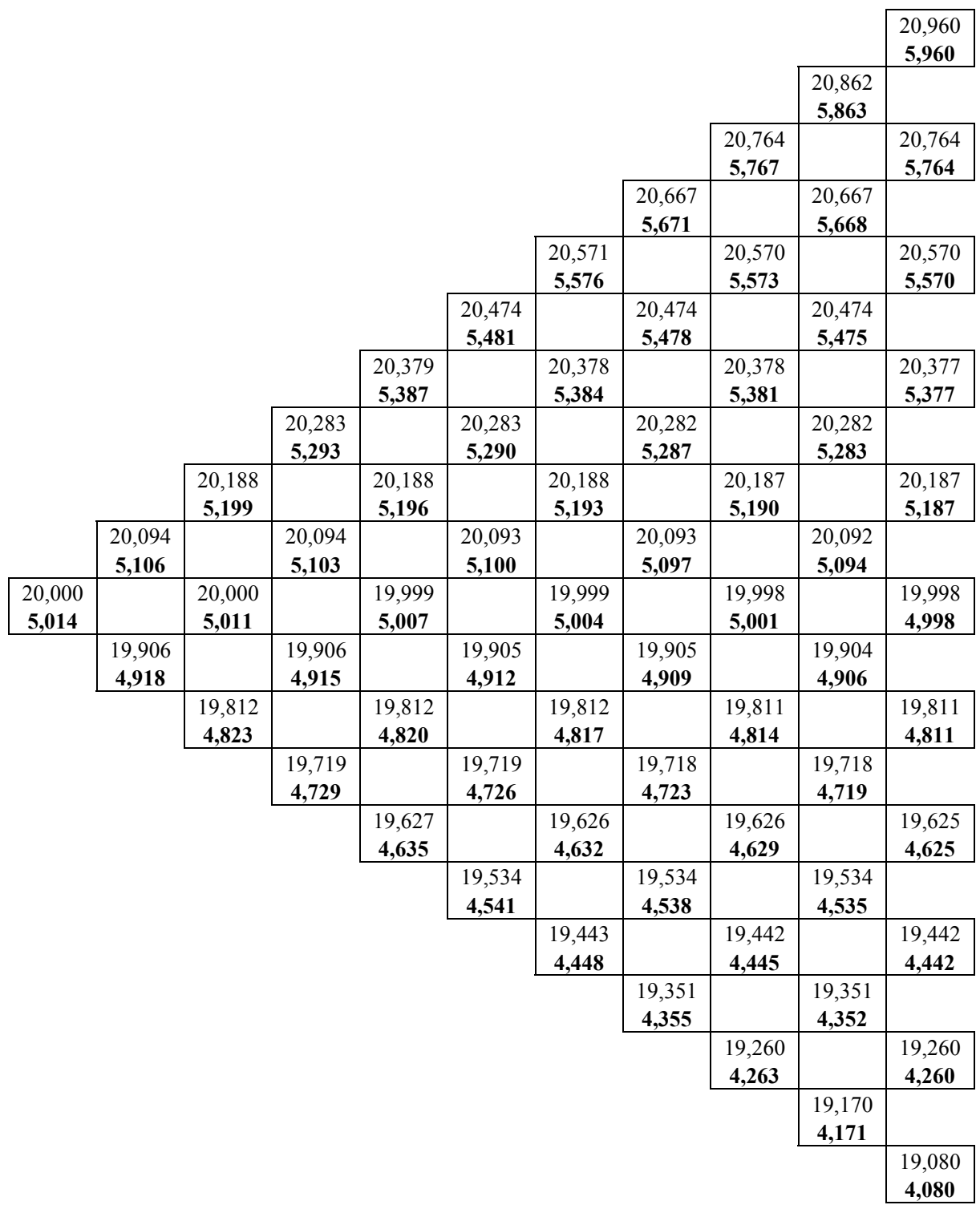

Obr. 4 Ocenenie call opcie pomocou binomického stromu (horná hodnota je vždy cena akcie, dolná hodnota je cena opcie $\mathrm{v}$ danom bode $\mathrm{v}$ strome)

Metódou binomických stromov bola určená cena call opcie so zadanými parametrami na $c=\$ 5,014$.

\section{Porovnanie:}

Pomocou Black - Scholesovho modelu bola cena danej opcie stanovená na $c=5,026$, z binomického stromu $c=5,014$. Skutočná cena opcie vypočítaná z Black - Scholesovho vzorca je 5,015. Obe metódy dávajú dostatočne presné výstupy. Chyba metódy binomických stromov je \$0,001, chyba metódy oceňovania pomocou Black - Scholesovho vzorca a Monte Carlo je v tomto prípade $\$ 0,011$. 


\section{Záver}

Uvedené dve numerické metódy výpočtu ceny call opcie sa dajú použit' pre l'ubovol'né parametre $S, X, r, \mu, \sigma, \Delta t$. Simuláciu vývoja ceny akcie môžeme opakovat' l'ubovol'ný počet krát, vývoj ceny akcie môžeme simulovat' na l'ubovol'ný počet krokov. Presnost' odhadu sa zvyšuje s rastúcim počtom opakovaní simulácie a so zmenšujúcou sa dížkou časových krokov.

Chyba Monte Carlo metódy je nepriamo úmerná druhej mocnine počtu opakovaní simulácie, teda ak chceme dosiahnut' 10 - násobnú presnost', musíme zvýšit' počet opakovaní 100 krát. Pri generovaní výberu z normálneho rozdelenia je možné použit' aj iný generátor pseudo-náhodných čísel (napr. kongruenčný generátor), ktorý má tú výhodu, že chyba odhadu je nepriamo úmerná počtu opakovaní simulácie, nie jeho druhej odmocnine. Dôležitá pri tejto metóde je teda správna vol'ba generátora náhodných čísel.

Metóda binomických stromov sa dá použit' pre ocenenie l'ubovol'ného derivátu. Jej nevýhodou je časová náročnost' výpočtu, ak chceme dosiahnut' vyššiu presnost' výpočtu, je potrebné zvolit' viac časových krokov menšej dížky. S rastúcim počtom krokov sa zvyšuje počet bodov v strome, pri oceňovaní path - dependent opcií sa tento počet po každom kroku zvyšuje niekol'konásobne. Metóda binomických stromov pracuje s diskrétnym časom.

\section{Literatúra}

[1] Hull, J. C.: Options, Futures, and Other Derivatives. 3. vyd. New York: PrentiCe Hall, 1997. 572 s. ISBN 0131864793

[2] ŠEVČOVIČ, D.: Analytické a numerické metódy oceňovania finančných derivátov. Dostupné na: <http://www.iam.fmph.uniba.sk/institute/sevcovic/skripta/derivaty/index. html>

[3] JÄCKEL, P.: Monte Carlo Methods in Finance. 1. vyd. Chichester, West Sussex, England: J. WILEY AND SONS, 2002. 222 s. ISBN 0-471-49741-X

[4] Chovancová, B. - JankovskÁ, A. - Hájniková, J. - Majcher, M. - Šturc, B.: Finančný trh: nástroje, transakcie, inštitúcie. 1. vyd. Bratislava: EUROUNION, 1999. 538 s. ISBN 8088984033 